\title{
Factors Affecting Job Performance of Security Personnel
}

\author{
Joefel T. Libo-on, Ph.D. ${ }^{1 *} \quad$ Augusto D. Tayco, Jr., Ph.D. ${ }^{2}$ \\ 1. Graduate Education and Professional Studies, Romblon State University, Odiongan, Romblon, Philippines \\ 2. Institute of Criminal Justice Education, Romblon State University Odiongan, Romblon, Philippines \\ *E-mail: onemanbrave@gmail.com
}

\begin{abstract}
Crimes suddenly decrease during a pandemic but this does not follow that security guards' job performance follows the same direction. The current investigation focuses on the job performance and factors that affect the job performance of the school security guard in Naga City which shows that security personnel was predominantly young, males, and married. The majority of the security personnel were high school graduates and are new in the security service. Security personnel-respondents are good at performing other duties and are always on their posts. The insecurity in the job tenure-based from performance evaluation is the major agency-related factor perceived to affect security guards' job performance and the respondents do not receive due recognition for their accomplishments. Security guards' job insecurity affects their job performance and the main family-related factor affecting security guards' job performance is the poor condition of their families. The internal factors have no bearing on the security guards' job performance both in technical functions and behavioral aspects while the external factors had an impact or effect on the job performance of the security personnel along the behavioral aspect. Security personnel's sex and civil status can explain their behavioral aspect of job performance while sex can explain the technical aspect.
\end{abstract}

Keywords: External Factors, Job Performance, Security Guard, Security Personnel, Internal, Philippines DOI: $10.7176 / \mathrm{JRDM} / 82-01$

Publication date: January $31^{\text {st }} 2022$

\section{Introduction}

There is a decline in the crime against the property during the pandemic (UNODC, 2020; Marquez, 2020; Stickle \& Felson, 2020). Despite statistical decline property owners, businessmen and even government agencies know that they cannot be fully protected by police officers because of insufficient supply of personnel, equipment, budget, and others. They sort to the services of private security agencies/guards to protect their lives and properties (Stom et.al, 2010). Private security agencies have been organized for giving protection to business establishments, banks, educational institutions, hospitals, subdivisions, and other big entities for purpose of security.

The security profession is as complicated as they must serve their clients honestly and responsibly. But to serve with complete honesty and responsibility, security guards must likewise perform their job enthusiastically. To be enthusiastic, the guard must be contented with his jobs, that he loves his works; he cares for the clients to whom he is assigned and he is loyal to the agency from where he is employed. In return, the agency management's action on the general welfare of its security personnel needs to be given serious attention; so that both parties can harmoniously reciprocate to each other.

Security is a basic need of man. According to McLeod (2020) in Maslow's hierarchy of needs puts safety and security needs second in the hierarchy for survival. First, the psychological needs. But once these are satisfied, man craves for the next higher need which is safety and security from bodily harm, security for the property and the future.

As a physical and psychological need, employees desire a safe working environment that would also provide economic security.

Article III, Section 2 of the 1987 Philippine Constitution states that:

The rights of the people to be secured in their persons, houses, papers, and effects against unreasonable searches and seizures of whatever nature and for any purpose shall be inviolable...

Over the years, the private security industry has had its ups and downs, depending largely on the supervision and administration of the government. There have been reports of fly-by-night operations that offered lower costs to clients but which were later found out to be inefficient and incapable of delivering security services at all. This could be the result of the laxity which could have triggered the issuance of the necessary permits to undeserving applicants for the operation of private security agencies, and the necessary licenses to non-qualified individuals desirous of becoming private security guards.

Several security agencies in Naga City assign security personnel to the different establishments within the city. Considering the number of clientele to be served is composed of business establishments; schools, colleges, and universities; hospitals, hotels, banks, and other entities, security agencies aspire for quality service just as the clientele expects satisfactory performance. 
Management of security agencies has to consider that one of their most critical tasks is the selection, training, and development of people who would best help the organization attain its goal. Likewise, the factors which affect the satisfactory performance of the security personnel should be settled.

According to the Industrial Security Guards Manual, Security Guards are considered the backbone of the security industry who is the "secret business partners" of the investors, for being the custodian or protectors of businessmen's interests, assets, and properties; hence they deserve, among others, modest salary, remunerations, and benefits by law. Providing such legitimate benefits helps in boosting one's morale and uplifting one's spirit. Therefore, the key to improving the effectiveness of the guard operation is to remove or lessen the obstacles to improved job performance such as low morale, low use of abilities, low social status, low pay, and benefits (Poonin, 2011). In this manner, the security management's action on the general welfare of its security personnel needs to be given serious attention. The adequacy of the system of compensation for the security personnel with responsiveness and prompt attention to their needs of the security personnel.

Generally, this study is to determine the internal and external factors that affect the job performance of the security personnel in colleges and universities in Naga City. Specifically, this will (1) determine the level of the job performance of the respondents in terms of (1. a) technical functions; and (1.b.) behavioral skills; (2.) to determine the internal factors that affect job performance along; and (3) to determine the external factors that affect job performance; (4) determine the relationship of external and internal factors with job performance; and determine which among the personal and professional factors can explain the job performance of the security personnel.

\section{Methodology}

This current study focused on the factors that affect the job performance of the security personnel assigned in the colleges and universities in Naga City. This investigation provides the profile of the security personnel which includes their age, sex, civil status, educational attainment, years in service, and position/ranks. Job performance of the security personnel was evaluated by the security personnel themselves, selected employees and students of the five colleges and universities in Naga City namely: Ateneo de Naga University, Bicol State College of Applied Sciences and Technology, Mariners Polytechnic Colleges Foundation-Naga Campus, University of Nueva Caceres and the University of Sta. Isabel.

The external and internal factors that affect the performance of the security personnel were included in this study. The total population of security personnel in every school was considered. The randomly selected student leaders and employees per school to evaluate the performance of the security personnel assigned in their institution. The respondents of this study (Table 1) were divided into three (3) groups; the security guards themselves, selected students and employees of five colleges and universities in Naga City which include University of Nueva Caceres (UNC), Ateneo de Naga University (ADNU), University of Sta. Isabel (USI), Mariners Polytechnic Colleges Foundation-Naga Campus (MPCF), and Bicol State College of Applied Sciences and Technology (BISCAST). That security personnel who are assigned in other cities were excluded in this study.

The descriptive-evaluative method was used to determine the job performance of the respondents in terms of technical functions; and behavioral skills; internal factors that affect job performance along: agency related and school related; and external factors that affect job performance in terms of self-related and home/family-related. The correlational method was used to find out whether internal and external factors do significantly contribute to the performance of the security personnel and whether their personal and professional characteristics significantly affect their job performance.

Table 1 Distribution of Respondents

\begin{tabular}{c|c|c|c|c}
\hline \hline School & $\begin{array}{c}\text { Security } \\
\text { Personnel }\end{array}$ & Students & Employees & Total \\
\hline \hline ADNU & 22 & 30 & 30 & 82 \\
\hline BISCAST & 9 & 30 & 30 & 69 \\
\hline MPCF & 13 & 30 & 30 & 73 \\
\hline UNC & 16 & 30 & 30 & 76 \\
\hline USI & 10 & 30 & 30 & 70 \\
\hline Total & $\mathbf{7 0}$ & $\mathbf{1 5 0}$ & $\mathbf{1 5 0}$ & $\mathbf{3 7 0}$ \\
\hline \hline
\end{tabular}

\section{Results and Discussion}

\subsection{Personal and Professional Characteristics of Security Personnel}

Personal. The age, gender, and civil status of security personnel assigned in five colleges and universities in Naga City (Table 2A) show that $40 \%$ of this security personnel was in the ages of 24-30 years old, very close to the age bracket of 31-37 years old (38.57\%). Only $2(2.86 \%)$ were in the age bracket of 51-56. It can be noted that security personnel assigned in five colleges and universities in Naga city was in the middle ages. 
More than 40 percent of the security personnel belong in the age range of 24-30 years old. In these ages, the security personnel must be alert in spotting violators. This can be attained by being watchful, dedicated, and diligent. Being physically strong is one of the attributes that a security guard should possess. Security work is strenuous and demanding. Physical conditioning is essential if he is to be a dependable guard. As to the sex or gender distribution, out of 70 security personnel, $62(88.57 \%)$ were males while only $8(11.43 \%)$ were females. This means that the security profession is more applicable for men than women. Although there is no discrimination in the application for this kind of work between men and women, it is already given that the security profession is dominated by men because of its masculine nature of work. However, females are also important in the security profession in searching the body of the female clients like students, employees, and especially, the visitors.

As to civil status, the table shows that $63(90 \%)$ of the security personnel assigned in colleges and universities in Naga City were married while $7(10 \%)$ of them were not married. It can be inferred that married people are attracted to the security profession. The married security personnel needs to support their family in terms of basic needs like food, education of their children, etc.

Professional. Looking into the professional characteristics of security personnel (Table 2B), most of the respondents were predominantly high school graduates which were represented by $39(55.11 \%)$ while the college graduates were 31 (44.29). The reason why the population of the respondents was dominated by high school graduates is that it is the minimum educational attainment required for security guards (RA 5487, Sec.5).

The number of years in the service means the length of the stay of the respondents in the security service. In this study, it can be noticed from the data that $31(44.29 \%)$ of the respondents were in the security service for 4 years and below which is more than one-third of the total population of the respondents. As to the rank or position of the security personnel, 66 (94.29) possessed the rank of security guard 1 or watchman while only 4 were security officer. It can be noticed that most of the security personnel assigned in colleges and universities in Naga city were security guards 1 . Their main task is about patrolling and checking the persons going in and out of the school premises.

Their function was focused on the safety and security of the institution, employees, and students. A similar study conducted by Poonin (2008) which he found out that in the security profession, the majority of guards belong to the rank-and-file, simply because they are the backbone of the security industry where the success of the business depends on the performance of the ordinary guards or watchmen.

Table 2 Personal \& Professional Characteristics

\begin{tabular}{|c|c|c|}
\hline Characteristics & Frequency & Percent \\
\hline \multicolumn{3}{|l|}{ - } \\
\hline $24-30$ & 28 & 40.00 \\
\hline $31-37$ & 27 & 38.57 \\
\hline $38-43$ & 8 & 11.43 \\
\hline $44-50$ & 5 & 7.14 \\
\hline $51-56$ & 2 & 2.86 \\
\hline \multicolumn{3}{|l|}{ Gender } \\
\hline Female & 8 & 11.43 \\
\hline Male & 62 & 88.57 \\
\hline \multicolumn{3}{|l|}{ Civil Status } \\
\hline Unmarried & 7 & 10.00 \\
\hline Married & 63 & 90.00 \\
\hline Total & 70 & 100.00 \\
\hline
\end{tabular}

(A)

\begin{tabular}{|c|c|c|}
\hline Characteristics & Frequency & Percent \\
\hline \multicolumn{3}{|l|}{ Educational Attainment } \\
\hline College Graduate & 33 & 44.29 \\
\hline High School Graduate & 39 & 55.71 \\
\hline Total & 70 & 100.00 \\
\hline \multicolumn{3}{|l|}{$\begin{array}{l}\text { Total } \\
\text { Years in Service }\end{array}$} \\
\hline 4 years and below & 3 & 44.29 \\
\hline 5-7 years & 15 & 21.43 \\
\hline $8-11$ years & 20 & 28.57 \\
\hline $12-14$ years & 2 & 2.86 \\
\hline 15 years and above & 2 & 2.86 \\
\hline Total & 70 & 100.00 \\
\hline \multicolumn{3}{|l|}{ Rank/Position } \\
\hline Security Officer & 4 & 5.71 \\
\hline Security Guard 1 & 66 & 94.29 \\
\hline Cecuin y Total & 70 & 100.00 \\
\hline
\end{tabular}

(B)

\subsection{Level of Job Performance of Security Personnel}

Technical Functions. The level of the job performance of security personnel along technical functions (Table 3A) was rated by the security personnel themselves, selected employees of the institution, and selected students. The security personnel was Performing other duties as directed with a mean rating of 3.46 which is described as very high. Next in rank was patrolling around the school premises with a mean rating of 3.45 which is very close to the previous rank. Meanwhile, the least rating was in the Submission of the written report if the situation warrants it. Performing other duties as directed was the most performed by the security guards from among the seven indicators. These other duties are those ordered by their supervisors or administrators which are not included in the job description of the security guard. Patrolling around the school premises placed $2^{\text {nd }}$ in rank. This is the primary duty of the security guards especially in schools and universities to monitor and keep safe whoever is inside the premises (Singh, 2021). In a school with a wide land area, patrolling is very important especially at night to monitor possible threats or entrance points of unauthorized persons, checking of unclosed offices, etc. Submission of the written report if situation warrants were placed last because employees and students were not aware of the security personnel assigned in the institution were submitting reports if the situation warrants. These reports were given to the one who is in charge to supervise the security personnel.

Based on the results, it can be deduced that security personnel performing their tasks well which was evidenced by the mean rating of 3.42 described as "very high". This very high description will give assurance to the safety and security of the institutions or schools. 
Table 3A Level of Job Performance of Security Personnel along with Technical Function

\begin{tabular}{|c|c|c|c|c|c|c|}
\hline Indicators & $\begin{array}{c}\text { Security } \\
\text { Personnel }\end{array}$ & Students & Employees & WM & Description & $\mathrm{R}$ \\
\hline Performance of other duties as directed & 3.64 & 3.33 & 3.41 & 3.46 & $\mathrm{VH}$ & 1 \\
\hline Patrolling around the school premises & 3.61 & 3.33 & 3.41 & 3.45 & VH & 2 \\
\hline Monitoring and control & 3.57 & 3.36 & 3.37 & 3.44 & $\mathrm{VH}$ & 3 \\
\hline Maintain confidentiality of school, employees and students information & 3.50 & 3.41 & 3.37 & 3.43 & VH & 4.5 \\
\hline Coordination with school administrators and staff & 3.57 & 3.39 & 3.31 & 3.43 & $\mathrm{VH}$ & 4.5 \\
\hline Respond to emergency situations in school premises & 3.56 & 3.37 & 3.31 & 3.41 & $\mathrm{VH}$ & 6 \\
\hline Submission of written report if situation warrants & 3.59 & 3.29 & 3.30 & 3.39 & VH & 7 \\
\hline 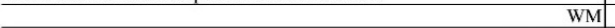 & 3.58 & 3.35 & 3.35 & 3.43 & $\mathrm{VH}$ & \\
\hline Description & $\mathrm{VH}$ & $\mathrm{VH}$ & $\mathrm{VH}$ & $\mathrm{VH}$ & & \\
\hline$R$ & 1 & 2 & 3 & & & \\
\hline
\end{tabular}

Legend: 3.26-4.00=Very High (VH); 2.51-3.25=High $(H) ; 1.76-2.50=$ Low $(L) ; 1.00-1.75=$ Very Low $(V L)$

Behavioral Skills. Behavioral skills mean how the security personnel treats the students and employees of the institution and their actions and behavior while they are performing their duties. The level of performance of the security personnel was rated by the security personnel themselves, employees, and students.

The rating of the Security Personnel runs first with a weighted mean of 3.55; followed by students' rating $(\mathrm{WM}=3.23)$; placed on third is the Employees' rating with a weighted mean of 3.16. All of the ratings were described as "very high".

The visibility and professionalism as an indicator run first with a mean rating of 3.34 while the least ranked was given to courtesy with a mean rating of 3.27 . The overall rating of behavioral skills of the security personnel was 3.32 described as "very high". Results show that the security personnel in colleges and universities in Naga city was always present or visible in their place of assignment. Visibility is very important in the security profession because it eliminates the possible threats or would-be violators in committing violations inside the school premises.

They also showed professionalism in the discharge of their duties. It is also important in the security profession to avoid the security personnel from committing violations like verbal abuse to the clients, performing duties while intoxicated and other violations.

It can be gleaned that the security personnel conforms to the Ethical Standards of Security Personnel which states that: (a) He shall at all times be courteous, respectful and salute his superior officers, government officials, and officials of the establishment where he is assigned and the company he is supposed to serve; (c) He shall report for duty always in proper uniform and neat in his appearance; (d) He shall wear his uniform, badge, patches, and insignia properly as a symbol of public trust and confidence, as an honest and trustworthy security guard and private detectives (RA 5487). This ethical standard is designed to guide the security guards on their daily actions, especially in the behavioral aspect while they are performing their duty.

Table 3B Level of Job Performance of Security Personnel along with Behavioral Skills

\begin{tabular}{l|c|c|c|c|c|c}
\hline \multicolumn{1}{c|}{ Indicators } & Security Personnel & Students & Employees & WM & Description & R \\
\hline Visibility & 3.56 & 3.37 & 3.09 & 3.34 & VH & 1.5 \\
\hline Professionalism & 3.56 & 3.32 & 3.14 & 3.34 & VH & 1.5 \\
\hline Punctuality and Attendance & 3.59 & 3.15 & 3.26 & 3.33 & VH & 3 \\
\hline People skills & 3.54 & 3.29 & 3.04 & 3.29 & VH & 4 \\
\hline Courtesy & 3.50 & 3.03 & 3.29 & 3.27 & VH & 5 \\
\hline WM & 3.55 & 3.23 & 3.16 & 3.32 & VH & \\
\hline Description & VH & VH & H & VH & & \\
\hline R & 1 & 2 & 3 & & & \\
\hline \hline
\end{tabular}

\subsection{Factors Affecting Security Personnel's Job Performance}

Internal Factors. Among the related factors that affect job performance, it shows that insecurity of job tenure through performance evaluation $(\mathrm{M}=3.07)$ and poor recognition of guards' good deeds/accomplishments $(\mathrm{M}=3.07)$ stands as the main internal factor that affects the job performance of the security guards. While the poor treatment to guards/employees $(\mathrm{M}=2.83)$ is the least factor that affects the job performance.

The performance evaluation system is administered in such a way as to foster the improvement of individual efficiency, effectiveness, and behavioral discipline as well as the promotion, retention, or removal from the job of the security personnel (Amistoso et al., 2019). It only means that through performance evaluation, the security guards will know their weaknesses they need to improve.

On the other hand, if the security personnel determined that their performance is high through performance evaluation, their morale will be high which will contribute to their good performance.

Low salary and benefits also affect the performance of the security personnel as this only means that the security personnel is not only motivated by the salary but also achievement through performance evaluation. As according to Kurt (2021) the Herzberg's Motivation-Hygiene Theory acknowledges the complexity of the salary issue and concluded that money is not a motivator in the way that the primary motivators are, such as achievement and recognition.

Lack of opportunity for promotion is also observable in the result because, in the security profession, a security guard can only be promoted if he undergoes required training. Training is very important for a security guard to 
perform well. Training provides further skills and advances the knowledge of the guard as well. Upgrading personnel in work is necessary so that they can be more effective in performing their duty. Drabek, Lorincova. \& Javorcikova (2017) and World Bank (2018) views education/training as a process of capital investment that brings gains that return to the individual and society. The improvement of the productive capacity of the human workforce is a form of capital investment. From the point of view, when security guards undergo professional training, seminars, and workshops for competence, their knowledge and skills are upgraded and therefore ensure benefits to the individual and the agency.

Meanwhile, the treatment of employers and the opportunity to show abilities and potentials are very important in every profession. As in Mc Gregor's Theory Y where the typical employee is pressured to have the potential to learn and grow as well as to seek and accept responsibility, they will eventually improve and develop themselves once management gives them the chance to do so. Because management gives attention to the employees in the firm's activities, they feel that they are part of the organization's success, hence, the feeling of recognition is met, and their drive for accomplishment will naturally follow (SAUT, 2020). In the supportive model of management, the manager is urged to help employees to solve their problems, accomplish their work, and give job satisfaction.

Further, Shaikh (2017) discussed that effective managers know their employees need recognition and praise for their efforts and accomplishments. Employees also need to know their supervisor's door is always open for them to discuss any concerns they have that are affecting their ability to do their jobs effectively and impeding their satisfaction at the office. In the present study, if the employer shows good treatment, opportunities and abilities, the security guards will show their best to perform their duties.

As for the poor recognition of guards' good deeds/accomplishments, it can be inferred that the recognitions of the employees, students, administrations, and supervisors contribute to the performance of the security guards. A security guard who is always recognized by their immediate superiors for his good job will perform better because it will boost their morale. According to Hines (2010) no matter what position an employee holds at work, it is important for each person to feel they matter at work. If an employee does not feel that his or her contribution makes a difference, this will affect job performance. In this study, if the employers or clients recognize the work of the security personnel, the security personnel's morale will increase and they will perform their job with enthusiasm and eagerness. This was also supported by Robbins (2019) that people want to be seen and recognized, both as individuals and teams for their value, skills, and accomplishments. They want to know that their contribution is appreciated.

Further, if a security guard is working in a good environment, like in colleges and universities in Naga city which are famous for providing good quality of education and with good administration, it will also contribute to their level of performance. According \& Raheela (2015) employees spend so much time in their work environment each week, companies need to try to optimize working conditions. Such things as providing spacious work areas rather than cramped ones, adequate lighting, and comfortable workstations contribute to favorable work conditions. Providing productivity tools such as upgraded information technology to help employees accomplish tasks more efficiently contributes to job performance as well (Shaikh, 2017).

Based on the result, all the internal factors enumerated much affects $(\mathrm{WM}=2.93)$ the performance of the security personnel who are assigned in the colleges and universities in Naga city.

Table 4A Internal Factors Affecting Security Personnel's Job Performance

\begin{tabular}{|c|c|c|c|}
\hline Internal Factors & Mean & Description & Rank \\
\hline 1. Low salary and benefits & 3.03 & MA & $\begin{array}{ll}3 \\
3\end{array}$ \\
\hline 2. Lack of supports to guards/employees. & 2.92 & MA & \\
\hline 3. Poor treatment to guards/employees & 2.83 & MA & 11 \\
\hline 4. Inconsistent policies information and dissemination & 2.86 & MA & \\
\hline 5. Insecurity of job tenure through performance evaluation & 3.07 & MA & 1.5 \\
\hline 6. Poor recognition of guards' good deeds/accomplishments. & 3.07 & MA & 1.5 \\
\hline 7. Lack of training opportunities & 2.90 & MA & \\
\hline 8. Lack of opportunity for promotion & 2.94 & MA & \\
\hline 9. Lack of opportunities for advancement & 2.85 & MA & 10 \\
\hline 10. Lack of opportunity to show abilities and potentials & 2.87 & MA & \\
\hline 11. Poor working environment & 2.89 & MA & \\
\hline WM & 2.93 & MA & \\
\hline
\end{tabular}

Legend: $3.26-4.00=$ Very Much Affected (VMA); 2.51-3.25= Much Affected (MA); 1.76-2.50=Less Affected (LA); 1.00-1.75=Not Affected (NA)

External Factors. The external factors that affect the performance of security personnel along with selfrelated and home/family-related (Table 4B). Along with self-related factors, it was noted that there were three factors/parameters which were found to be above the general mean of 2.86 . The three leading factors were the following: Job insecurity with a mean rating of 3.19; lack of skills \& knowledge with a mean rating of 3.00; and, poor employee attitude with 9.97. All of these factors obtained an interpretation of "much affected". The last rank which was below the general mean was given to Vices such as smoking, drinking, and/or using illegal drugs. 
It can be gleaned from the result that job insecurity was the leading factor that affect the performance of the security personnel. It is because of the unequal distribution of the work to the security guards. Others may be overworked while others are not.

According to Hines, if the workplace is understaffed and an employee has more work than he or she can handle, this can cause someone to become very unhappy in the workplace. Ensuring that the job duties are divided for each person to handle is important. If one works for an office and he is the only person working diligently every day, it can cause someone to become unmotivated.

Each person needs to do his or her best in coming to the office to encourage the entire office to work hard. This will keep morale high when each person does his or her best.

Further, the lack of skills and knowledge of the security guard has a direct impact on his performance. If a security guard is under skilled or does not have enough knowledge about his work, it will contribute to his poor performance. Skills and knowledge, as well as employees' attitudes, are very important in the security profession. Since security guards deal with different types of people, they must have the skills and knowledge how to deal with people properly.

Vices such as smoking, drinking, and/or using illegal drugs also affect job performance. According to Republic Act 9165, the Comprehensive Dangerous Drugs Act of 2002, a person who is drug dependent, could not perform his duty without the influence of drugs. According to the code of conduct of security personnel of RA 5487, "he shall not drink any intoxicating liquor immediately before and during his tour of duty". Therefore, a drug-dependent person has no place in the security service. In this study, vices were ranked as the last factor that affects the respondents' performance, therefore, it has little or no effects on their performance.

As to home/family related, it was noted that the poor condition of the family gave much impact on the performance of the security personnel than the far distance of the workplace to the home which obtained mean ratings of 3.07 and 2.86 respectively. Both of these obtained a description of "much affected". According to Amistoso et al. (2019) the poor condition of the family means that it matters to the performance of the security personnel. In this study, if a security guard is dealing with difficult home life is almost certainly going to have their job performance affected. The encroachment of their troubles into their working day cannot be avoided. No matter what the issue is, managers need to act sympathetically towards these employees. Offering a change in shift pattern or working hours is one way of attempting to limit the impact the issue may have on that particular employee's overall performance.

This was supported by Papa (2017) who asserts that employees' family life can have a direct impact on their behavior. If there's a conflict in the family life, it can affect the employee's behavior at work. The employee may respond negatively to criticism at work and interaction with the leadership. Happiness at home can result in a motivated and happy employee.

As to the far distance of the home to the workplace, it has a big impact on the performance of the security guard, but in this study, it came out that it ranked last. It means that the residence of the respondents was not too far from their workplace.

Table 4B External Factors Affecting Security Personnel's Job Performance

\begin{tabular}{|c|c|c|c|}
\hline Factors & Mean & Description & Rank \\
\hline \multicolumn{4}{|l|}{ A. Self-Related } \\
\hline Job insecurity & 3.19 & MA & 1 \\
\hline Lack of skills \& knowledge & 3.00 & MA & 2 \\
\hline Poor employee attitude & 2.97 & MA & 3 \\
\hline Vagueness about role & 2.96 & MA & 4 \\
\hline Lack of job experience & 2.93 & MA & 5 \\
\hline Poor Work motivation & 2.89 & MA & 6 \\
\hline Low self-esteem & 2.81 & MA & 7 \\
\hline Lack of self-confidence & 2.77 & MA & 8 \\
\hline Absenteeism & 2.56 & MA & 9 \\
\hline Vices such as smoking, drinking, and/or using illegal drugs & 2.53 & MA & 10 \\
\hline WM & 2.86 & MA & \\
\hline \multicolumn{4}{|l|}{ B. Home/Family Related } \\
\hline The poor condition of the family & 3.07 & MA & 1 \\
\hline Far distance of the workplace to the home & 2.86 & MA & 2 \\
\hline e & 2.96 & MA & \\
\hline $\mathbf{C M}$ & 2.91 & MA & \\
\hline
\end{tabular}

Legend: $3.26-4.00=$ Very Much Affected (VMA); $.51-3.25=$ Much Affected (MA); 1.76-2.50=Less Affected (LA); 1.00-1.75=Not Affected (NA) 


\subsection{Relationship of External and Internal Factors with Job Performance}

The relationship between external and internal factors with job performance (Table 5) showed that the internal factors have no significant relationship to behavioral aspect $(\chi=266.526 ; \mathrm{p}=.599)$, also internal factors were found to have no significant relationship to the technical aspect of the performance of the security personnel $(\chi=99.194$; $\mathrm{p}=.641)$

On the other hand, the external factors were found to have a significant relationship to the behavioral aspect of the respondents $(\chi=399.409 ; \mathrm{p}=.038)$. Meanwhile, the external factors have no significant relationship to the technical aspect $(\chi=109.113 ; \mathrm{p}=.950)$.

Based on the result, it can be inferred that the behavioral skills of the security guards are affected by external factors. If a security guard arrives at work, he brings with him his moods, emotions, opinions, and problems at home or with life in general. Since an employee may need to cooperate with others to get the work done, his attitude will have a great influence on productivity, his relationships with others, and productivity on the job.

According to Richinick (2020), while most managers expect their employees to leave their personal life at the door when they come to work, that's not always possible. Outside factors, such as marital and family issues, financial struggles, or illness can influence job performance.

Table 5 Relationship between External and Internal Factor with Job Performance

\begin{tabular}{c|c|c|c}
\hline \hline Variables & $\chi$-Value & p-Value & Description \\
\hline \hline Internal Factors and & & & \\
\hline Behavioral Aspect & 266.526 & .599 & $\mathrm{NS}$ \\
\hline Technical Aspect & 99.194 & .641 & $\mathrm{NS}$ \\
\hline External Factors and & & & \\
\hline Behavioral Aspect & $399.409^{*}$ & .038 & $\mathrm{~S}$ \\
\hline Technical Aspect & 109.113 & .950 & $\mathrm{NS}$ \\
\hline \hline
\end{tabular}

Legend: ${ }^{\mathrm{ns}} p>.05=$ Not Significant $(\mathrm{NS}) ;{ }^{*} p<.05=$ Significant $(\mathrm{S})$

\subsection{Predictors of Job Performance}

The personal and professional factors of the security personnel were also considered in the current investigation (Table 6). It had been found out that the personal and professional factors have a medium relationship $(\mathrm{R}=.429)$ towards the behavioral aspect of job performance. Among the factors sex and civil status can explain the behavioral aspect of performance of the security personnel which can be defined by $\mathrm{y}=4.536-.336 \mathrm{x}_{2}-.439 \mathrm{x}_{3}$; where: $\mathrm{y}=$ behavioral aspect job performance; $x_{2} \in \mathbb{N} \leq 2,1=$ male and $2=$ female; and $x_{3} \in \mathbb{N} \leq 5,1=$ single, $2=$ married, $3=$ single parent, $4=$ =widow/widower. $5=$ separated. The determining factor of the behavioral aspect has a coefficient of determination of .184 however the adjusted coefficient of determination of .129 tells us that the behavioral aspect of the job performance can be explained by sex and civil status by $12.9 \%$. Result is same to the finding of Ugwu (2016) that sex and civil status is the predictor of job performance.

On the part of the technical aspect of job performance, it was found that $\operatorname{sex}(B=-.79 ; p=0.004)$ is the factor that can explain the performance among the other five factors. Looking at the relationship of the personal and professional factors towards technical aspect it is also in a medium relationship $(\mathrm{R}=.445)$. But taking into account that sex is the factor that can explain technical aspect job performance by .143 or $14.3 \%$. The technical aspect of job performance can be determined by $\mathrm{y}=4.664-.356 \mathrm{x}_{2}$; where: $\mathrm{y}=$ behavioral aspect job performance; $x_{2} \in \mathbb{N} \leq 2$ , $1=$ male and $2=$ female.

The results implied that the security profession is suitable for both men than women. Although there is no discrimination in the application for this kind of work between men and women, it is already given that the security profession is dominated by men because of its masculine nature of work. However, females are also important in the security profession in searching the body of the female clients like students, employees, and especially, the visitors.

As to the civil status, it can be inferred that married people are attracted to the security profession. The married security personnel needs to support their family in terms of basic needs like food, education of their children, etc. Poonin (2008) in his study, most security personnel who are married are responsible enough to perform their duties and to support their family. These might be the reason why the city status was found in this study as one of the personal factors that contribute to the performance of the security personnel. 
Table 6 Predictors of Job Performance

\begin{tabular}{|c|c|c|c|c|}
\hline \multirow{3}{*}{$\begin{array}{c}\text { PERSONAL AND PROFESSIONAL } \\
\text { FACTORS }\end{array}$} & \multicolumn{4}{|c|}{$\begin{array}{l}\text { JOB PERFORMANCE } \\
\end{array}$} \\
\hline & \multicolumn{2}{|c|}{ Behavioral Aspect } & \multicolumn{2}{|c|}{ Technical Aspect } \\
\hline & $\mathrm{B}$ & $\mathrm{p}$ & $\mathrm{B}$ & $\mathrm{p}$ \\
\hline Constant & 4.536 & & 4.664 & \\
\hline Age $\left(\mathrm{x}_{1}\right)$ & $.080^{\mathrm{ns}}$ & .191 & $-.180^{\mathrm{ns}}$ & .205 \\
\hline $\operatorname{Sex}\left(\mathrm{x}_{2}\right)$ & $-.338 *$ & .005 & $-.356 *$ & .004 \\
\hline Civil Status $\left(\mathrm{x}_{3}\right)$ & $-.439 *$ & .005 & $.065^{\mathrm{ns}}$ & .535 \\
\hline Educational Attainment $\left(\mathrm{x}_{4}\right)$ & $-.033^{\mathrm{ns}}$ & .288 & $.082^{\mathrm{ns}}$ & .586 \\
\hline Length of Service $\left(\mathrm{x}_{5}\right)$ & $.212^{\mathrm{ns}}$ & .190 & $-.091^{\mathrm{ns}}$ & .395 \\
\hline Position/Rank $\left(\mathrm{x}_{6}\right)$ & $-.135^{\mathrm{ns}}$ & .143 & $.182^{\mathrm{ns}}$ & .112 \\
\hline$R$ & \multicolumn{2}{|c|}{.429} & \multicolumn{2}{|c|}{.445} \\
\hline$R^{2}$ & \multicolumn{2}{|c|}{.184} & \multicolumn{2}{|c|}{.198} \\
\hline Adjusted $R^{2}$ & \multicolumn{2}{|c|}{.129} & \multicolumn{2}{|c|}{.143} \\
\hline$F$ & \multicolumn{2}{|c|}{3.314} & \multicolumn{2}{|c|}{3.619} \\
\hline$p$ & \multicolumn{2}{|c|}{.005} & \multicolumn{2}{|c|}{.003} \\
\hline
\end{tabular}

Legend: $\mathrm{B}=$ regression coefficient; $\mathrm{p}=$ probability value; ${ }^{\mathrm{ns}} p>.05=$ Not Significant; ${ }^{*} p<.05=$ Significant

\section{Conclusions and Recommendations}

The security personnel was predominantly young, males, and married. The majority of the security personnel were high school graduates and are new in the security service. The agencies should consider hiring female security guards to promote gender sensitivity because a large population of students belongs to the female group. Also, the hiring of older security personnel must be taken into account since students pay more respect to them because of their age than those who are young. Training, capacity buildings, and other related activities for personal and professional development must be provided to security personnel for efficiency enhancement.

Security personnel-respondents are good at performing other duties and they are always on their posts. The security guards should be trained in Information and Communications Technology (ICT) skills for prompt and punctual submission of reports and send online reports to the head office. Seminars on customer relations should be given regularly to remind and equip security guards with the proper courtesy and right conduct in dealing with clients.

The insecurity in the job tenure-based from performance evaluation is the major agency-related factor that affects security guards' job performance and security guards do not receive due recognition for their accomplishments. Scholarship, capacity building, career advancement, and development must be offered among security guards for a study now or train now pay later scheme to provide them other alternatives and support in case their services are no anymore needed. Mechanisms on rewards and incentives must be reviewed and improved to duly recognize the good deeds and accomplishments of those high-performing security guards to boost their morale, maximize their services and strengthen their loyalty.

Security guards' job insecurity affects their job performance and the main family-related factor affecting security guards' job performance is the poor condition of their families. The agency should collaborate with the clients to provide more security benefits for security personnel in terms of cash and kind and other material resources and if possible provide scholarships for the children of the security personnel. Security guards' civil status and sex can explain the behavioral aspect of performance while sex only for the technical aspect. The agency should also hire female security guards for gender balance or gender sensitivity. Unmarried security guards should also be hired because they have the potential to perform their job well if they would be trained and motivated well.

\section{References}

Abdul, R. \& Raheela M. (2015) Impact of Working Environment on Job Satisfaction, Procedia Economics and Finance, Volume 23, 2015, Pages 717-725, ISSN 2212-5671, https://doi.org/10.1016/S2212-5671(15)005249.

Amistoso, J., Etcuban, J. O., Llamedo, E., Gimena, J. A., Capuyan, D., \& Lumantas, B. (2019). Performance Management System of a Security Agency in the Philippines. Asian Journal of Managerial Science, 8(2), 1421. https://doi.org/10.51983/ajms-2019.8.2.1558

Drábek, J., Lorincova, S. and Javorcikova, J. (2017). Investing in Human Capital as a Key Factor for the Development of Enterprises, Issues of Human Resource Management, Ladislav Mura, IntechOpen, DOI: 10.5772/67741. Available from: https://www.intechopen.com/chapters/54434

Kurt, Serhat (2021) Herzberg's Motivation-Hygiene Theory: Two-factor. https://educationlibrary.org/herzbergsmotivation-hygiene-theory-two-factor/

Marquez, C (2020) As pandemic led to crime decline, it also gave rise to abuses. The Inquirer.net https://newsinfo.inquirer.net/1376281/as-pandemic-led-to-crime-decline-it-also-gave-rise-to-abuses

Martins, Andre et al. (2017) Factors influencing job satisfaction at Thai Nguyen University, Faculty of Information 
Technology

McLeod, www simplypsychology (2020). Maslow's

Papa, Nicole (2017) Internal \& external factors that influence employee behavior https://www.pocketpence.co.uk/organizational-culture-negative-effects-8211344.html

Poonin, O M. (2008) Common Problems Affecting Delivery Of Security Services By XXX Ssecurity \& Investigation Services", Undergraduate Thesis for the Degree of Bachelor of Science in Criminology, Lucena City. https://www.scribd.com/document/373093123/ABSTRACT-Dedication-Sample

Republic Act No. 5487. An Act to Regulate the Organization and Operation of Private Detective, Watchmen or Security Guards Agencies. (Rep. Act No. 5487, as amended by Presidential Decree No. 11.)

Republic Act No. 9165 "Comprehensive Dangerous Drugs Act Of 2002".

Richinick, Michele (2020) Workplace Etiquette: 21 Dos and Don'ts of the Workplace. Northeastern University Graduate Program. https:/www.northeastern.edu/graduate/blog/workplace-etiquette/

Robbins, Mike (2019) Why Employees Need Both Recognition and Appreciation. Harvard Business Review.https://hbr.org/2019/11/why-employees-need-both-recognition-and-appreciation

Robbins, Mike (2019) Why Employees Need Both Recognition and Appreciation. Harvard Business Review.https://hbr.org/2019/11/why-employees-need-both-recognition-and-appreciation

SAUT (2020) Prospectus https://saut.ac.tz/downloads/SAUT\%20Prospectus\%2020192020\%20Academic\%20Year.pdf

Shaikh, Assma Parvez(2017)A comparative analysis of job satisfaction level of assistant professors working in management colleges in india and saudi arabia. http://hdl.handle.net/10603/153573

Singh, Ranga (2021) A security guard duties and responsibilities in the workplace. https://www.closecareer.com/general-duties-and-responsibilities-of-security-guard/

Stickle, B., \& Felson, M. (2020). Crime Rates in a Pandemic: the Largest Criminological Experiment in History. American journal of criminal justice: AJCJ, 1-12. Advance online publication. https://doi.org/10.1007/s12103-020-09546-0

Strom, Kevin, et al. (2010) The Private Security Industry: A Review of the Definitions, Available Data Sources, and Paths Moving Forward https://www.ojp.gov/pdffiles1/bjs/grants/232781.pdf

Ugwu, Mercy E. (2016) Demographic Variables as Predictors of Job Performance of Librarians in Federal University Libraries in South East Nigeria

UNODC (2020) Effect of the COVID-19 pandemic and related restrictions on homicide and property crime. https://www.unodc.org/documents/data-and-analysis/covid/Property_Crime_Brief_2020.pdf

World Bank (2018) Building Human Capital. The Changing Nature of Work. https://doi.org/10.1596/978-1-46481328-3 ch3 